\title{
The Preference Size Of Male Mud Crab, Scylla tranquebarica at Success Mating With Female, Scylla olivacea in Controlled Tanks
}

\author{
${ }^{1}$ Gunarto, Sulaeman and Herlinah \\ ${ }^{1}$ Research Institute for Coastal Aquaculture and Fisheries Extension Maros, 90512 South Sulawesi, Indonesia. \\ Email:gunartom@yahoo.com
}

Received: 7 October 2019; Accepted: 22 November 2019

\begin{abstract}
Gunarto, Sulaeman and Herlinah. 2019. The Preference Size Of Male Mud Crab, Scylla tranquebarica at Success Mating With Female, Scylla olivacea in Controlled Tanks. Aquacultura Indonesiana, 20(2) : 93 - 101. Interspecific hybridization of mud crab Scylla spp has been successfully conducted in controlled tanks. However, there is no information yet available about the male size $S$. tranquebarica is capable to copulate with female of $S$. olivacea. The objectives of the experiment is to find out the male size of $S$. tranquebarica that willingly copulated with newly molted female of S. olivacea. Twelve individual of adolescent female of $S$. olivacea were reared individually in the conical fibreglass tanks each of $500 \mathrm{~L}$ volume. In another tank, 12 adult male $S$. tranquebarica with various size (200-500g/ind.) were also prepared. The crabs fed with chopped trash fish in the morning (7.00 am) and afternoon (17.00 pm) at 5\% of the total crab biomass. Each newly molted female is transfered to the prepared copulation tank where three male of different size have been placed and allow them to mate and freely copulated with the female. The size of copulated crabs (body weight, carapace with, and carapace length) were recorded. The female sizes were measured before and after molting, whereas, the male sizes were measured soon after mating process has finished. Post mating, the female crab then reared individually in the recirculating tank system until mature and spawned. The result showed that male $S$. tranquebarica with individual weight of $>300 \mathrm{~g}$ are preferable to copulate with female $S$. olivacea, where in contrary no male crab of the size $<300 \mathrm{~g}$ were successfully mate. The duration from mating to gonad maturity stage IV for the hybridized S. olivacea in this study ranges between 59103 days.
\end{abstract}

Keywords : Scylla olivacea, Scylla tranquebarica, preferences, mating, mature gonade

\section{Introduction}

Mud crab, Scylla spp are brackish water commodities that have high economic value, both locally and internationally (Keenan, 1999; Ikhwanuddin et al, 2010), therefore intensive captured has been occured in Cenranae estuary, Bone regency, South Sulawesi and has cause a sign of over exploitation (Gunarto et al, 1999). One visible sign of overexploitation in this area is early mature population from time to time become smaller and smaller and recently reach 100$200 \mathrm{~g}$. On the other hands, mud crab culture in ponds has been carried out in a number of mud crab producing regions in Indonesia using wild crab seeds (Gunarto and Sulaeman, 2017).

Based on observations, the distribution of $S$. tranquebarica in Indonesian waters is predominantly in the West Papua, Sout whereas the larvae of South Sulawesi, begin eating artemia nauply on the seventh
Sulawesi, Southeast Sulawesi, East Kalimantan, South coast of Central Java. $S$. tranquebarica is considered has higher growth rate compared to the other species where from crablet size of $0.05-0.5 \mathrm{~g}$ could reach consumption size at 200-300 g) after 3-4 months cultivated in ponds (Syafaat and Gunarto, 2018). Thus this crab species is very prospectus to be cultivated in ponds.

The first maturation size of female $S$. tranquebarica is $76.8 \pm 7.02 \mathrm{~mm}$ in carapace length, $112.2 \pm 9.01 \mathrm{~mm}$ in carapace width, and $232.6 \pm 41.1 \mathrm{~g}$ total body weight (Gunarto et al, 2017). The size of larvae from the female mud crab broodstock from Balikpapan (1.061 $\pm 0.028 \mathrm{~mm}$ ) was greater than the size of the larvae from the South Sulawesi $(0.796 \pm 0.056$ $\mathrm{mm})$. Furthermore, the larvae from broodstock of Balikpapan are able to accept artemia nauply from fourth days after hatching (DAH),

DAH. With the presence of larvae that more quickly consume nauplius artemia, thus easing 
the work in the hatchery in terms of rotifer mass culture which is used as larvae feed.

In order to get a superior mud crab among the available mud crab species, hybridization is a must. Research on crossbreeding of mud crab has been carried out by several researchers such as Baiduri et al (2014), where they concluded that breeding of mud crab can be done in controlled tanks. Furthermore, Waiho et al (2015) stated that the success of mating of mud crabs in a controlled tank is not influenced by sex ratio, but is influenced by the stocking density of mated crabs. The crab seeds obtained from crossbreeding grow faster and reached marketable size at $260.402 \pm 57.25 \mathrm{~g}$ (Gunarto et al, 2017), while mud crab seeds obtained from individual selection reached $185.68 \pm 38.75 \mathrm{~g}$, and from the normal one only reached $156.98 \pm 15.30 \mathrm{~g}$ after five months cultured in brackishwater pond (Gunarto et al, 2019a). The interspecific hybridization between female of $S$. paramamosain and male of $S$. tranquebarica resulted in egg fecundity of $32,200-1,868,000$, hatching rate of $2-45 \%$, whereas for S. olivacea female copulated with $S$. tranquebarica male produced egg fecundity of 758000 egg and hatching rate $98 \%$ (Gunarto et al, 2019b). The effort to make interspecific hybreedization between $S$. tranquibarica male and $S$. olivacea female needs to be done in the control tank. However, up to now still rare research reporting the interspecies hybridi zation of the mud crab, Scylla spp of both on the wild as well as in the controlled tank. Presumed wild hybrid of mud crab Scylla serrata and $S$. olivacea in Japan had been reported by Imai and Takeda (2005). Invation of $S$. olivacea to the habitat of $S$. serrata was presumed to caused the hybridization between these two species.

In this research we effort to make interspecies hybridization between male of $S$. tranquebarica and female of S. olivacea in the controlled tank. To minimise canibalisms among the crab, then the male and female crabs are cultured individually in each tank until find out a new molt female crab in the tank, then started to copulated that a new molt female of $S$. olivacea with various size of male $S$. tranquebarica. The difference in size of male crabs $S$. tranquebarica, is likely related to the male capability to copulate with S.olivacea female and may related to the maturity status and also related to sperm quality as well as the vitality of the spermatozoa produced. The size preference of
S. tranquebarica male crabs which mating with $S$. olivacea female crabs was the focus of this study. Thus the aims of the study was to determine the size of male crabs that most often mating with $S$. olivacea female crabs.

\section{Material and Method}

Mating Trial. Cross-breeding tests between species ( $S$. tranquibarica male and $S$. olivacea female) were carried out as follows:

A total of 12 adolescent female stage of S. olivacea with mean individual weight (W) of $177.72 \pm 25.17 \mathrm{~g}$ and mean carapace width (CWi) $97.59 \pm 6.38 \mathrm{~mm}$, were reared individually in a conical fiberglass tanks whith diameter of $60 \mathrm{~cm}$ and height $100 \mathrm{~cm}$ filled with $500 \mathrm{~L}$ of sand filtered sea water salinity 30 ppt. The all tanks jointed each other by means of polyvinyl chloride (pvc) pipe set it up in recirculation system. Another 12 rectangular tanks sized of $100 \times 100 \times 50 \mathrm{~cm}$ were prepared for 12 male crab of $S$. tranquebarica. The rearing system here exactly the same as for the female crab except for male crabs were consisted of three different size groups namely a). The $\mathrm{W}$ ranged between 400-500 $\mathrm{g}$ and CWi 127.77 \pm 4.19 $\mathrm{mm} ; \mathrm{b})$. W ranged between 301-399 $\mathrm{g}$ and CWi $115,12 \pm 4.91 \mathrm{~mm} ; \mathrm{c})$. W ranged between 200-300 g with CWi of $111.77 \pm 2.09 \mathrm{~mm}$. Before being stocked into the rearing tanks, all crabs were measured in CWi using calipers to the neares $0.1 \mathrm{~mm}$, and $\mathrm{W}$ using an electrical balance to the nearest $0.1 \mathrm{mg}$. Feed in the form of trash fish and squid were given in an et libitum to stimulate molting. Water replacement is done every 3 days as much as $50 \%$ of the total volume in the recirculation system. Monitoring is carried out along day and night to observe molting female in the tanks. The newly molted female was immediately transferred to the mating tank where three male crab each of with different size have been stocked. When there is no mating activity within 15 minutes after the stocking time, then all male crabs were replaced with three other males from the rearing tank. Female replacement is repeated until one male interested to copulated with the newly molted female. Once a wanted male is found, then the other males were returning back to the original tank. When the mating is 
finished, the mated male crab is also returned to its original tank.

The duration of the copulation process and the size of copulated crabs (male and female) were recorded. In three day after mating (DAM) the female crab is taken out from the copulation tank and dipped in 150 ppm of $10 \%$ formalin solution for a minute and returned back to conical fiberglass tank. The mated female fed with chopped trash fish given et libitum until mature and spawned. The gonad maturity stage is classified according to Roberston dan Kruger (1994) by opening the back side of carapace.

The spawned female was dipped in 150 ppm of $10 \%$ formalin solution for 2 minutes before its moved into the incubation tank. The incubation tank is a cylindrical fiberglass tank filled with $500 \mathrm{~L}$ sterilized sea water with gentle aeration. Egg fecundity data is calculated based on the method of Churchill, (2003). The water quality parameter in the rearing tanks were measured for their salinity, $\mathrm{pH}$, water temperature and dissolved oxygen with a YSI Professional Plus Multy DO meter. To observe the actual gonadal status of male, a male from different sizes were euthanized before they were freezed $-5^{\circ} \mathrm{C}$ for 30 menit and open up , the carapace to showed up testes. The testis and vas deferent were taken and preserved in Bouin solution for histological sections.

Data on individual size, duration time of mating, egg fecundity, and gonad histology were presented in tables and figures and explained descriptively.

\section{Results and Discussion}

Hibrydization of mud crabs in which $S$. tranquibarica male crabs from Malili, South Sulawesi versus female $S$. olivacea crabs from Maros, are shown in Table 1. From the time of mating recorded showed that crab mating almost every month from February to May 2019 , and projected to continue to the rest of the month. However, there is clearly appear a peaks of the mating season. Although no mating crab on March 2019 was occurred because the expected mating female was dead during molting process. From five mating pairs, three males $(60 \%)$ of the $\mathrm{W}$ of $324-375 \mathrm{~g}$ (CWi, 107.8-120.6 mm) and two males (40\%) with a larger size at the range of W $417-457 \mathrm{~g}$ (CWi 123.4-126.6 mm). While no mating occurred at the smallest male size, W 200$300 \mathrm{~g}$ (CWi 111.5-120.1 mm). This is probably related to the level of readiness/maturity of male crabs and the level of aggressiveness of male to approach female. In this case male $S$. tranquebarica at the size of $\mathrm{W}>300 \mathrm{~g}$ is the most ready to copulates with newly molted female of $S$. olivacea compared to $\mathrm{W}$ of $<300 \mathrm{~g}$.

The reproductive organs of male $S$. tranquebarica comprises two distinct part, the testis and the shorter vas deferens. The testis is flat and coiled, located at the anterior part of the hepatopancreas and below the cardiac stomach (Ikhwanuddin et al, 2018). In this research, the testis of male crab with body weight less than $300 \mathrm{~g}$ still in immature stage (Figure 1a), while testis in crab with body weight more than $300 \mathrm{~g}$ had been in mature stages (Figure 1b).

Gonad development in male crab was classified into three stages, namely 1). Immature (spermatogonia), 2). Maturing (Spermatocytes), 3). Mature (Spermatids and Spermatozoa). Testis histological section showed that testis of male mud crab with size less than $300 \mathrm{~g}$ still immature was represented by gonad with spermatogonia and primary spermatocytes (Figure 2a), while male mud crab with body weight of more than $300 \mathrm{~g}$ was mature representated by gonad contain of spermatozoa and the presence of spermatids (Figure 2b). Islam and Kurokura (2012) reported that the mean size at first sexual maturity of male S. olivacea is $103 \mathrm{~mm}$ carapace width. From the data measurement showed that male $S$. tranquebarica which successfully mated with new molt female $S$. olivacea in this research with $\mathrm{CWi}$ at the ranges of 107.8-126.6 $\mathrm{mm}$ and the body weight per individual at the ranged of 324.6$457 \mathrm{~g}$. 
Table 1. The size of male, S. tranquebarica and female, S. olivacea mating in controlled tanks

\begin{tabular}{lllllll}
\hline $\begin{array}{c}\text { Date of } \\
\text { mating }\end{array}$ & \multicolumn{3}{c}{ Male crab S. tranquebarica } & & \multicolumn{2}{l}{ Female crab, S. olivacea } \\
\hline & $\begin{array}{l}\text { Weight } \\
(\mathrm{g})\end{array}$ & $\begin{array}{l}\text { Carapace } \\
\text { width } \\
(\mathrm{mm})\end{array}$ & $\begin{array}{l}\text { Carapace } \\
\text { length } \\
(\mathrm{mm})\end{array}$ & $\begin{array}{l}\text { weight }(\mathrm{g}) \\
\text { before and } \\
\text { after molt }\end{array}$ & $\begin{array}{l}\text { Carapace width } \\
(\mathrm{mm}) \text { before and }\end{array}$ & $\begin{array}{l}\text { Carapace length } \\
(\mathrm{mm}) \text { before and }\end{array}$ \\
& & 107.8 & 75.4 & $234.2(274.3)$ & $105.5(121.8)$ & $75.6(82.4)$ \\
$12 / 2$ & 324,6 & 126.6 & 87.9 & $164.3(242.5)$ & $91.8(114.4)$ & $64.6(78.8)$ \\
$12 / 2$ & 417 & 123.4 & 86.6 & $185.0(214.6)$ & $105.7(107.9)$ & $71.6(78.2)$ \\
$02 / 4$ & 457 & 120.6 & 79.3 & $140.1(332.6)$ & $90.0(121.7)$ & $65.0(85.1)$ \\
$13 / 4$ & 340.6 & - & - & $194.4(325.0)$ & $105.0(126.5)$ & $71.0(84.3)$ \\
$28 / 4$ & - & 116.8 & 78.2 & $170.8(234.0)$ & $97.2(105.5)$ & $64.2(72.3)$ \\
$23 / 5$ & 375 & & & & &
\end{tabular}

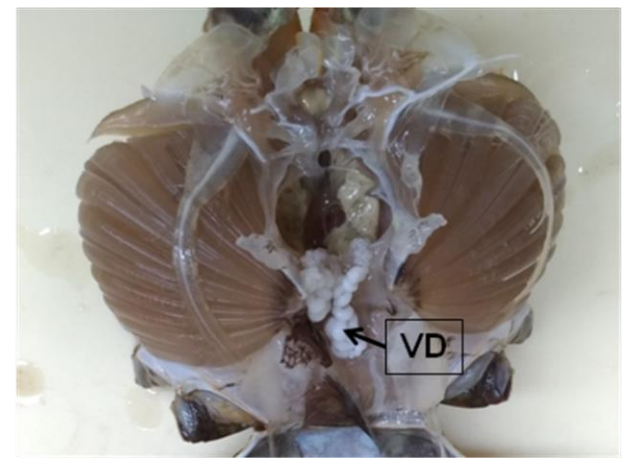

(a)

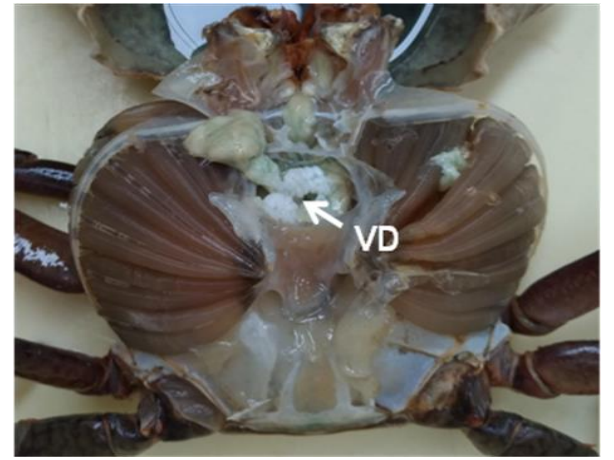

(b)

Figure 1. Male crab S. tranquebarica with immature testis (a) and mature testis (b), VD: Vas Deferens

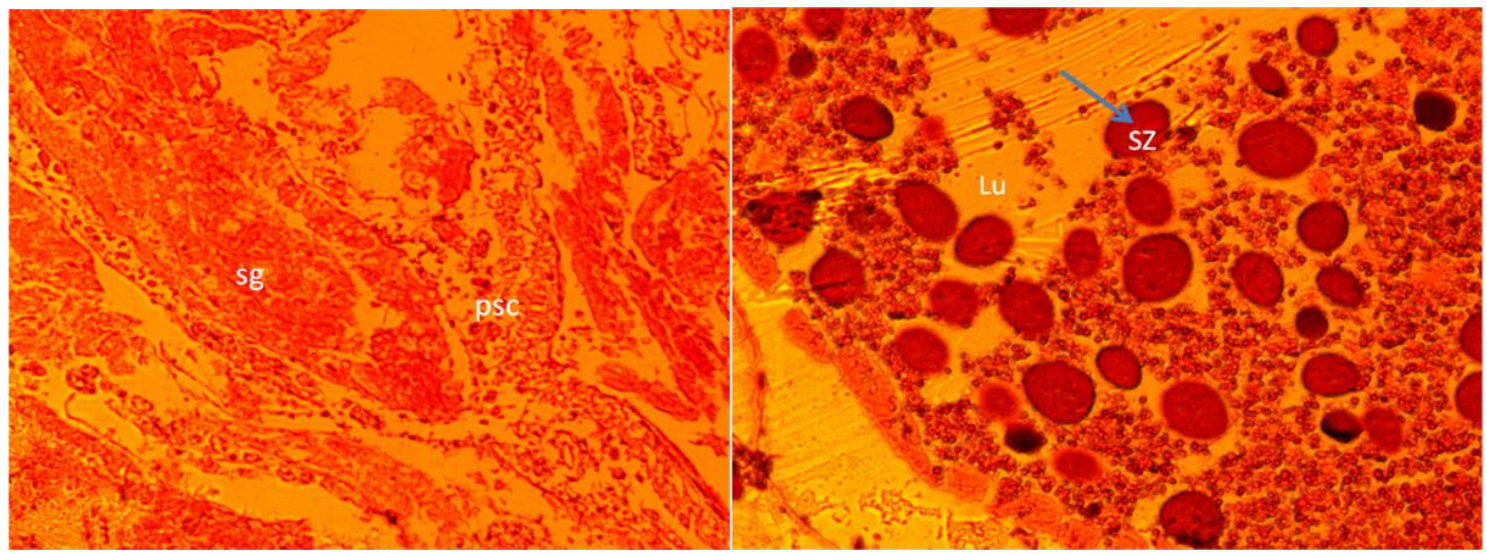

(a)

(b)

Figure 2. Histological section of testis for S. tranquebarica (a). Immature (sg : Spermatogonia and primary spermatocyte), (b). Matured ( $\rightarrow$ sz : spermatozoa and Lu : lumen) (magnification of 40x).

A new molted female crab was obtained in this research mostly occurs when the water in the tank was replaced with the new coming sea water. Otherwise, molted crab in the wild may correlated with the high tide of tidal cycle and may changed the water salinity and temperature gradient during tidal cycle. Pracopulation process often occurs before crab mating, where the male pairing female before the female crab molted and usually take time during 3-5 days. The male crab often help hands to the molting process of female, especially when they got hard to escape from the old carapace. However, in this research pracopulation process was eliminated with aims to minimize canibalisms to the newly molted crab when male and female crabs pooled together in the same tank. The size (W) of adolescent stage of female $S$. olivacea before molting ranged 140.1-234.2g (CWi, 90.0-105.5 mm) and after molting and mating inreases to 214.6-340.6 g (CWi 107.9-121.8 
$\mathrm{mm}$ ). When the copulation occurs (Figure 3), the process sperm transfer from the male to the seminal receptor female can take place only immediately after molting process is finished where the seminal receptacle is very small inside of female abdoment.

Mating success on hybridization of male $S$. tranquebarica and female $S$. olivacea is $41.7 \%$. This result is quite high compared to $30 \%$ as reported by Baiduri et al (2014). This differences may caused by different strategy apply in pairing the new molt female crab $S$. olivacea with male crab $S$. tranquebarica. The other important point is the way to stimulate the female to molt or shortern the period of intermolt phase, which will produced more female ready to be copulated. Then the hardness of carapace of adult male as the indication of mature male is also to be considered in working of mud crab breeding. Limb removing may be an alternative way that can be done to promote molting as has been proved bay several authors (Quinitio and Estepa 2011; Baiduri et al, 2014). However, the application on female brood stock as well as hormonal treatments is still need further experiment. In addition, the number of female crabs that are cultured need to be increased, so that the number of expected molting crabs will be more.

Based on the size of the mating males, the larger in size does not always win in competing to mate the female because the larger male are the most feared by smaller male and female crabs (Beattie et al, 2012). However, this research does not seems to be the case in the competition for mating newly molting female crabs. Ikhwanuddin et al (2010) reported that $S$. olivacea in Setiu
Wetlands, Terengganu, Malaysia was reached maturity at carapace width of $90.6 \mathrm{~mm}$ for female and $89.7 \mathrm{~mm}$ for male crabs, while according to Fatihah et al (2018) that the size of mature $S$. tranquebarica male broodstock is $280-350 \mathrm{~g}$. The length of the male crab approach to female crabs until copulation takes a short amount of time is only 10-20 minutes. While the mating process is divided into four stages, namely precopulation, molting, copulation, and postcopulation (Waiho et al 2015). In this research the process of mating was cut off into no precopulation process, because of male and female reared individualy in separated tank. By this technique is able to avoid mortality caused by canibalisms.

When the crab copulation occurred, the female crab extends her hinged abdomen, exposing two genital pores (gonopores) then the male crab inserts his gonopods into the genital pores and then transfers the seminal fluid which contains sperm sacs, called spermatophore to the female, where the sperm can be stored for months (Baiduri et al, 2014). While the copulation takes a long time which was 8-12 hours for male $S$. tranquebarica and female $S$. olivacea in this research and occurs both day time and night time.

Within a period of 6-133 days of culture of the 12 adolescent females $S$. olivacea, only $9(75 \%)$ molting female were obtained in the controlled tank, of which only five individual $(41.7 \%)$ successfully mated with male $S$. tranquebarica, one individual female $(8.3 \%)$ molting success but not mated by male and three individual $(25 \%)$ failed molting. Thus there are only three females that have not been molt during the experiment.

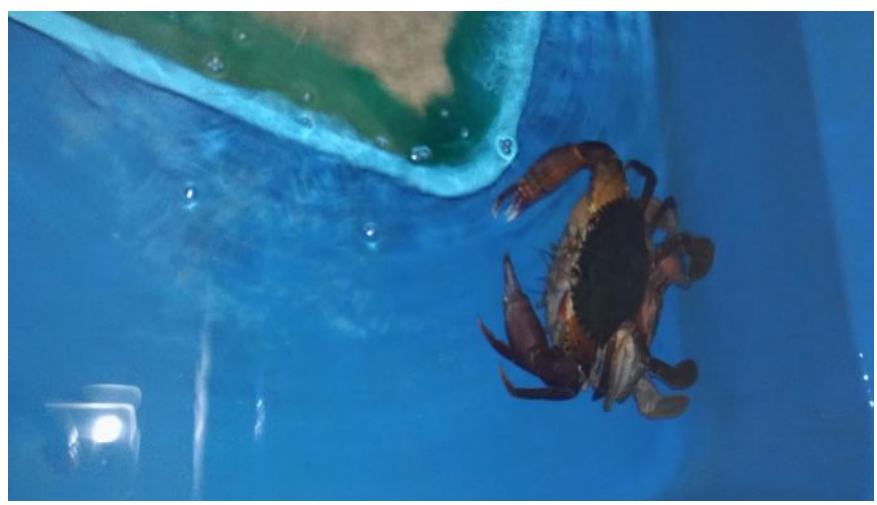

Figure 3. Male of $S$. tranquebarica mating with female $S$. olivacea in controlled tank 
In addition, the size (weight, length and width of carapace) difference between before and after molting of female $S$. olivacea is varies greatly. From the data obtained it appears that there is a tendency that the crab with the longer intermolt periods will resulted in largely increase in the size compared to crabs with shorter intermolt periods (Table 1).

The gonadal maturation stage of post mating female crab $S$. olivacea shows a difference after being cultured for a certain period of time. The post mating female crabs with Gonadal Mature Stage II were obtained after 133 days of cultured is presented in Figure 4. Even if the size has increase dramatically from $164.3 \mathrm{~g}$ (before molting) to
$242.5 \mathrm{~g}$ after molting, the gonad development is still very slow. The others post mating female crabs with Gonadal Matured Stage (GMS) III was obtained after cultured during period of 72 days (Figure 5). This also seems to have a slow gonad development. The post mating female crab with GMS IV was obtained after cultured for 59 days (Figure 6). Whereas other post mating female crab that have cultured for a period of 47 days has spawn (Figure 7). Based on these data had proven that the lengthen period of post mating female crab cultured in the tank is not ensure that their gonadal more develop compared to the shortern period of post
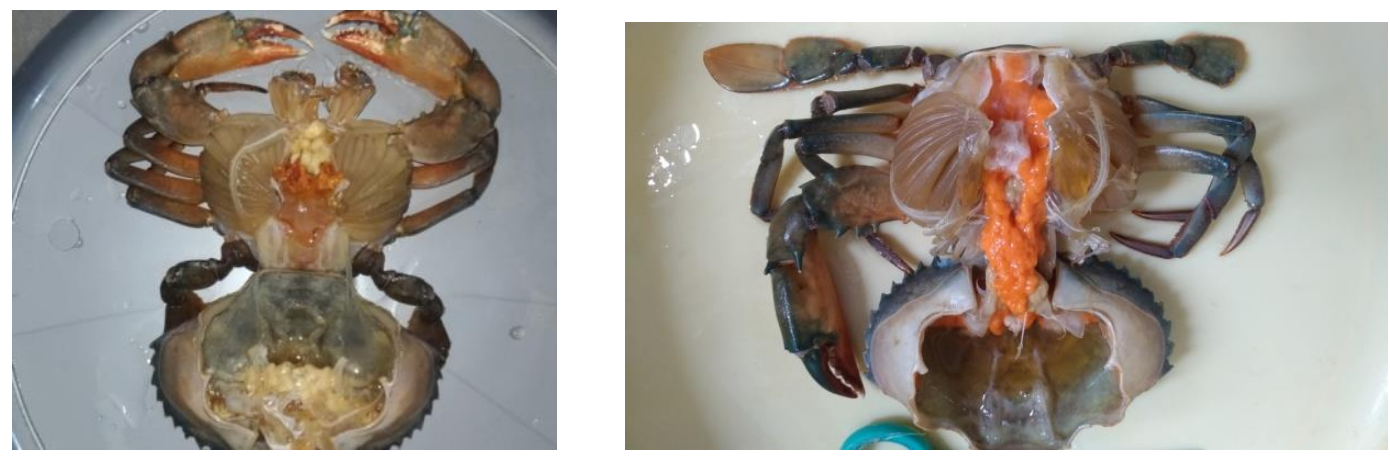

Figure 4. Female crabs S. olivacea with GMS II Figure 5. Female crabs S. olivacea with GMS III

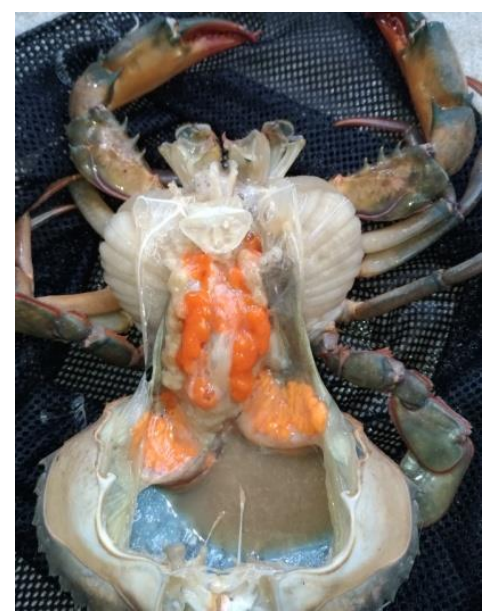

Figure 6. Female crab S. olivacea with GMS IV

mating female crab cultured in the other tank (Table 2). It is likely the gonadal development is also to be greatly influenced by the indigenous hormonal system of each individual post mating female crab. Whether this phenomena is correlated with the size male copulated pair or not is still unknown. From the Table 1 and Table 2 showing that male crab with size over than $400 \mathrm{~g}$ mating

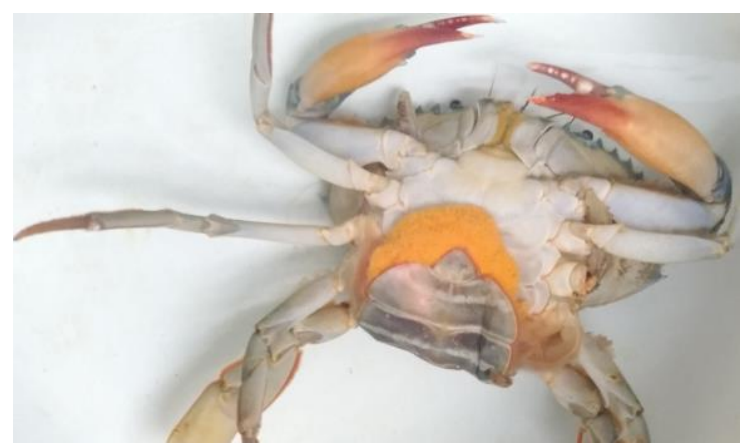

Figure 7. Female crab S. olivacea spawned

with new molted female with size more than $200 \mathrm{~g}$, resulted in the gonad stage II and stage IV after 103-133 days reared in tank. Whereas for the male crab with size less than $400 \mathrm{~g}$ mating with new molted female crab with size up than $200 \mathrm{~g}$, resulted in the gonadal stage III and IV after post mating female crab cultured during 47-72 days. There is no correlation between male size and acceleration of gonadal 
development in female crab. The feed that ingested by broodstock, healthy of broodstock and may also water temperature are influencing the gonadal development. Another researcher reported that eyestalk ablation (Anilkumar \& Adiyodi 1985), extract Morus alba (Fujaya et al 2014) and extract Melastoma malabathricum (Farizah et al, 2017) are able to stimulate gonadal maturation on mud crab, Scylla spp. The copulation duration between 8-12 hours and the approach to initiation of copulation and competition among male crab in the copulation tank was taken about 15-30 menit. The fecundity of the S. olivacea spawned was 231.831 egg (Figure 7). It seems the female $S$. olivacea broodstock resulted from interspecific hybridization between female $S$. olivacea with male of $S$. Tranquebarica is not fertile.

Table 2. Size of female crabs that mate and the time taken to attain level of Gonadal Mature Stage

\begin{tabular}{|c|c|c|c|c|c|c|c|}
\hline \multirow{2}{*}{$\begin{array}{l}\text { Date of } \\
\text { mating }\end{array}$} & \multicolumn{3}{|c|}{ Female mud crab } & \multirow{2}{*}{$\begin{array}{l}\text { Date of } \\
\text { spawned }\end{array}$} & \multirow{2}{*}{$\begin{array}{l}\text { Date of } \\
\text { die }\end{array}$} & \multirow{2}{*}{$\begin{array}{l}\text { Gonadal } \\
\text { Maturated } \\
\text { Stage }\end{array}$} & \multirow{2}{*}{$\begin{array}{l}\text { Days } \\
\text { required }\end{array}$} \\
\hline & $\begin{array}{l}\text { Total body } \\
\text { weight }(\mathrm{g})\end{array}$ & $\begin{array}{l}\text { Carapace width } \\
(\mathrm{mm})\end{array}$ & $\begin{array}{l}\text { Carapace } \\
\text { length }(\mathrm{mm})\end{array}$ & & & & \\
\hline $12 / 2$ & $234,2(274,3)$ & $105,5(121,8)$ & $75,6(82,4)$ & $2 / 4 / 2019$ & $\begin{array}{l}8 / 4 / 201 \\
9\end{array}$ & spawned & 47 \\
\hline $12 / 2$ & $164,3(242,5)$ & $91,8(114,4)$ & $64,6(78,8)$ & - & $\begin{array}{l}25 / 6 / 20 \\
19\end{array}$ & II & 133 \\
\hline $02 / 4$ & $185(214,6)$ & $105,7(107,9)$ & $71,6(78,2)$ & - & $\begin{array}{l}15 / 7 / 20 \\
19\end{array}$ & IV & 103 \\
\hline $13 / 4$ & $140,1(340,6)$ & $90(120,6)$ & $65,0(79,3)$ & - & $\begin{array}{l}25 / 6 / 20 \\
19\end{array}$ & III & 72 \\
\hline $23 / 5$ & $170,8(234)$ & $97,2(105,5)$ & $64,2(72,3)$ & - & $\begin{array}{l}22 / 7 / 20 \\
19\end{array}$ & IV & 59 \\
\hline
\end{tabular}

The water quality parameters such as salinity during culture period using recirculation system at $30-32$ ppt. It almost constant salinity because of the crab hatchery located near the beach at Lawallu village, Soppengriaja District, Barru Regency, South Sulawesi where ther is no freshwater surrounding the area. The Dissolved Oxygen (DO) concentration at the ranged between 5.27.3 ppm. The high concentration due to recirculation systems was applied in the culture system of both male and female crab in this research. Temperature affects metabolic activity which impacted to growth rate, activity and appetite of mud crabs. At low temperatures it can cause drastic reduce in activity and appetite for mud crabs. At that time growth will be hampered even though the mud crabs will still be alive. In this study based on data from the monitoring that showing to fluctuate from $27-29^{\circ} \mathrm{C} . \mathrm{pH}$ is also almost stable at 8.0-8.2. In waters that have sandy substrates tend to contain alkaline $\mathrm{pH}$. Shelley and Lovatelli (2011) established water quality standards for the mud crabs culture. Mud crab can survival at wide salinity range between 5-40 ppt, whereas for optimum growth at $10-25 \mathrm{ppt}$, but for broodstock in hatchery were held at the salinity 30-35 ppt. An optimum DO is up than 5 ppm. Optimum temperature for mud crab growth is $30^{\circ} \mathrm{C}$, but for the good growth at temperature $25-30^{\circ} \mathrm{C}$, and for broodstock held at the temperature 25 $32^{\circ} \mathrm{C}$ and $\mathrm{pH}$ of 7.5 to 8.5 .

\section{Conclusions}

Hybridization of mud crab Scylla spp in the wild is difficult to detected and my occurs among species. Therefore, hybridization could be conducted in controlled tank aimed to find out the crab seed with superiority such as larvae high vitality, crablet fast growth and less canibalisms. Male crab with size > 300/ind. are prefer to copulate with female $S$. olivacea compared to the size of $<300 \mathrm{~g} / \mathrm{ind}$. Testis of male crab with size of $<300 \mathrm{~g}$ still in immature stage which is represented by gonad with spermatogonia and primary spermatocytes. Testis in crab with size of $>300$ $\mathrm{g}$ had been in mature stages which was representated by gonad dominated by spermatozoa and the presence of spermatids. The shortest period from mating until mature gonad stage IV for the post mating female $S$. olivacea was 59 days. 


\section{Acknowledgments}

The authors are grateful to the Aquaculture Research Program DIPA 2019, Research Institute for Coastal Aquaculture and Fisheries Extension, Maros, Ministry of Marine Affairs and Fisheries for funding this research. The authors also appreciate the efforts of Sainal, Muhammad Syakaria towards the completion of this research.

\section{Referencees}

Anilkumar G., Adiyodi K., 1985 The role of eyestalk hormones in vitellogenesis during the breeding season in the crab, Paratelphusa hydrodromous (Herbst). The Biological Bulletin 169:689-695.

Beattie, C. L., Pitt, K. A., Connoly, R. M. 2012. Both size and gender of mud crabs influence the outcomes of interference interactions. Journal of Experimental Marine Biology and ecology 434-435:1-6.

Baiduri, S. N., Akmal, S. N and Ikhwanuddin, M., 2014 Mating success of hibrid trials between two mud crab species, Scylla tranquebarica and Scylla olivacea. Journal of Fisheries and Aquatic Science 9(2):85-91. DOI: 10.3923/jfas.2014.85.91

Churchill, G. J., 2003 An investigation into the captive spawning, egg characteristics and egg quality of the mud crab (Scylla serrata) in South Africa. Master Thesis in Rhodes University, South Afrika. $111 \mathrm{p}$.

Fatihah, S. N., Sylverter, C. S., Hasrul, H. H., Mucd-Farouk, H., Chen, C. A. 2018. Sperm viability and quantity of mud crab, Scylla tranquebarica in different cryoprotectants. AACL Bioflux 11(4): 1098-1106.

Gunarto, Daud R., Usman,1999. The trend of decreasing population of mud crab in Cenranae Estuary, Bone Regency, South Sulawesi, observed from their resources analysys. Indonesian Fisheries Research Journal 5(3): 3037.(in Indonesian).

Gunarto, Herlinah, Sulaeman, Syafaat, M. N., Ulo, T., and A. Parenrengi. 2017. Repairing production systems and contruction of broodstock candidate to supporting mud crab, Scylla spp domestication. Technical Report. Research Institute for Coastal Aquaculture, Maros. 22 p. (in Indonesian).

Gunarto and Sulaeman 2017 Rearing of mud crab, Scylla tranquebarica larvae with different stocking densities. Jurnal Omni Akuatika 13 (2):190-198. DOI: 10.20884/1.oa.2017.13.2.261.

Gunarto, Syafaat, M. N., and Herlinah. 2019a. Larva Development and Growth of Mangrove Crab, Scylla tranquebarica Crablet from Individual Selection for the Broodstock Candidate. Aquacultura Indonesiana 20 (1): 2431.

DOI:http://aquasiana.org/index.php/ai /article/view/132

Gunarto, Sulaeman and Herlinah. 2019b. Hybridization of Mud Crab, Scylla spp in Controlled Tanks. Research report of Research Institute for Coastal Aquaculture and Fisheries Extension, Maros. 10p.

Imai, H., and Takeda, M. 2005. A natural hybrid mud crab (decapoda, portunidae) from Japan. Journal of Crustacean Biology, 25(4): 620-624.

Ikhwanuddin, M., Bachok, Z., Mohd Faizal, W. W. Y., Azmie, G and Abol Munafi, A. B. 2010. Size at maturity of mud crab Scylla olivacea (Herbst, 1796) from mangrove areas of Terengganu coastal waters. Journal of Sustainable Science and Management 5(2):134147.

Ikhwanuddin, M., Azmie, G., Nahar, S. F., Wee, W., Azra, M. N., Abol Munafi, A. B. 2018. Testis maturation stages of mud crab (Scylla olivacea) broodstock on different diets. Sains Malaysiana 47(3): 427-432.

Islam, S., and Kurokura, H., 2012 male reproductive biology of mud crab Scylla olivacea in a tropical mangrove swamps. Journal of Fisheries and Aquatic Sciences 7(3):194-204. DOI:10.3923/jfas.2012.194.204

Farizah, N., Zairin, M., Jr., Darusman, L., K., Boediono, A., Suprayudi, A. M. 2017. Accelerated ovarian maturation of mud crab (Scylla olivacea) using ethanol extract of Melastoma malabathricum leaf. AACL Bioflux, 2017, Volume 10, Issue 4: 911-921. 
Fujaya Y., Trijuno D. D., Nikhlani A., Cahyono I., Hasnidar, 2014 The use of mulberry (Morus alba) extract in the mass production of blue swimming crab (Portunus pelagicus L.) larvae to overcome the mortality rate due to molting syndrome. Aquatic Science and Technology 2(1):2168-9148.

Robertson, W. D. dan Kruger, A., 1994. Size at maturity, mating and spawning in the portunid crab Scylla serrata (Forskal) in Natal, South Africa. Estuarine, Coastal and Shelf Science, $39: 185-200$.

Shelley, C., and Lovatelli, A. 2011. Mud crab aquaculture, a practical manual. FAO fisheries and aquaculture technical paper 567. Food and Agriculture Organization of the United Nations. 78p.

Syafaat, M. N and Gunarto, 2018 Growout culture of mud crab Scylla tranquebarica (Fabricius, 1798) from hatcheri in different pond location. Media Akuakultur 13 (1) : 21-30 http://dx.doi.org/10.15578/ma.13.1.20 18.21-30. (In Indonesia).

Waiho, K., Mustaqim, M., Fazhan, H., Norfaizza, W.I.W., Megat, F.H., \& Ikhwanuddin, M., 2015 Mating behaviour of the orange mud crab, Scylla olivacea: The effect of sex ratio and stocking density on mating success. Aquaculture Reports, 2 (2015) 50-57. Http://dx.doi.org/10.10 16/j.aqrep.2015.08.004 